\title{
Role of platelet-derived endothelial cell growth factor/thymidine phosphorylase in fluoropyrimidine sensitivity
}

\author{
M de Bruin', T van Capel', K Van der Born', FA Kruyt', M Fukushima², K Hoekman', HM Pinedo' \\ and GJ Peters*,I
}

'Department of Medical Oncology, VU University Medical Center, De Boelelaan II 17, 1081 HV Amsterdam, The Netherlands; ${ }^{2}$ Taiho Pharmaceutical Co. Ltd., I-27 Misugidai, Hanno-Shi, Saitama 357-8527, Japan

\begin{abstract}
Platelet-derived endothelial cell growth factor (PD-ECGF)/thymidine phosphorylase (TP) catalyses the reversible phosphorolysis of thymidine to thymine and 2-deoxyribose- I-phosphate and is involved in the metabolism of fluoropyrimidines. It can also activate $5^{\prime}$ deoxyfluorouridine (5'DFUR) and possibly 5-fluorouracil (5FU) and Ftorafur (Ft), but inactivates trifluorothymidine (TFT). We studied the contribution of TP activity to the sensitivity for these fluoropyrimidines by modulating its activity and/or expression level in colon and lung cancer cells using a specific inhibitor of TP (TPI) or by overproduction of TP via stable transfection of human TP. Expression was analysed using competitive template-RT-PCR (CT-RT-PCR), Western blot and an activity assay. TP activity ranged from nondetectable to $70678 \mathrm{pmol}^{-1} 10^{-6}$ cells, in Colo320 and a TP overexpressing clone Colo320TPI, respectively. We found a good correlation between TP activity and mRNA expression $(r=0.964, P<0.01)$ in our cell panel. To determine the role of TP in the sensitivity to 5FU, 5'DFUR, Ft and TFT, cells were cultured with the various fluoropyrimidines with or without TPI and differences in IC 50 's were established. TPI modified 5'DFUR, increasing the IC 50 's 2.5- to I396-fold in WiDR and Colo320TPI, respectively. 5Fluorouracil could be modified by inhibiting TP but to a lesser extent than 5'DFUR: IC $50^{\prime}$ 's increased 1.9- to I4.7-fold for WiDR and Colo320TPI, respectively. There was no effect on TFT or Ft. There appears to be a threshold level of TP activity to influence the $5^{\prime}$ DFUR and 5FU sensitivity, which is higher for 5FU. Even high levels of TP overexpression only had a moderate effect on 5FU sensitivity.
\end{abstract}

British Journal of Cancer (2003) 88, 957-964. doi: 10.1038/sj.bjc.6600808 www.bjcancer.com

(c) 2003 Cancer Research UK

Keywords: thymidine phosphorylase; 5-fluorouracil; 5'-deoxyfluorouridine; ftorafur; trifluorothymidine; thymidine phosphorylase inhibitor

Platelet-derived endothelial cell growth factor (PD-ECGF) is an angiogenic factor discovered in the late 1980s (Miyazono et al, 1987; Ishikawa et al, 1989). Sequence analysis of the gene revealed a stretch of 120 amino acids to be identical to thymidine phosphorylase (TP), an enzyme catalysing the reversible phosphorolysis of thymidine to thymine and 2-deoxyribose-1-phosphate (dR-1-P) (Furukawa et al, 1992). Subsequently, this enzymatic activity was identified for PD-ECGF (Moghaddam and Bicknell, 1992; Usuki et al, 1992). The two enzymes are considered to be identical and are designated as TP. The protein is expressed in normal tissues and cells, including macrophages, Kupffer cells, endothelial cells, ovary, salivary gland and brain (Fox et al, 1995). Increased TP expression, compared to normal tissue, was found in breast (Moghaddam et al, 1995), bladder (O’Brien et al, 1995, 1996), gastric (Takebayashi et al, 1996a), colorectal (Takebayashi et al, 1996b), lung (Giatromanolaki et al, 1998) cancer and several other tumours in numerous histochemical studies. In general, a high TP has been shown to be a prognostic factor for poor survival in gastric and colorectal cancer (Takebayashi et al, $1996 \mathrm{a}, \mathrm{b}$; Matsumura et al, 1998; van Triest et al, 2000), but in oesophageal

*Correspondence: Dr GJ Peters; E-mail: gj.peters@vumc.nl

Received 16 July 2002; revised II December 2002; accepted II December 2002 carcinoma there are conflicting reports (Ikeguchi et al, 1999; Koide et al, 1999) about its prognostic significance.

Besides its angiogenic action, the enzymatic activity of TP plays a role in fluoropyrimidine sensitivity, being able to activate 5fluorouracil (5FU) and $5^{\prime}$-deoxyfluorouridine (5'DFUR) (Ackland and Peters, 1999), and an increased expression was related with a better outcome of treatment with 5FU and its derivatives (Fox et al, 1997; Saito et al, 1999). The potential actions of TP in the metabolism of various fluoropyrimidines are depicted in Figure 1. TP activates $5^{\prime}$ DFUR to $5 F U$ by cleaving the 5-deoxyribose moiety, while by addition of 2-deoxyribose-1-phosphate TP can activate $5 \mathrm{FU}$ to 5 -fluoro- $2^{\prime}$-deoxyuridine, a precursor of FdUMP which inhibits thymidylate synthase, responsible for de novo thymidylate synthesis. Recently, there is renewed interest in the role of TP, since it activates $5^{\prime} \mathrm{DFUR}$, an intermediate in Capecitabine (Xeloda) metabolism to 5FU. Capecitabine is a newly designed oral fluoropyrimidine carbamate which is converted to $5 \mathrm{FU}$ in three steps, the first step is catalysed by carboxyl esterase located almost exclusively in the liver, the second step by cytidine deaminase expressed in the liver and various types of tumours, and the last by TP which is higher in tumours than in normal tissues thus ensuring an enhanced efficacy (Miwa et al, 1998).

Trifluorothymidine (TFT) has previously been used in antiviral therapy and has been evaluated for cancer therapy as a single agent 


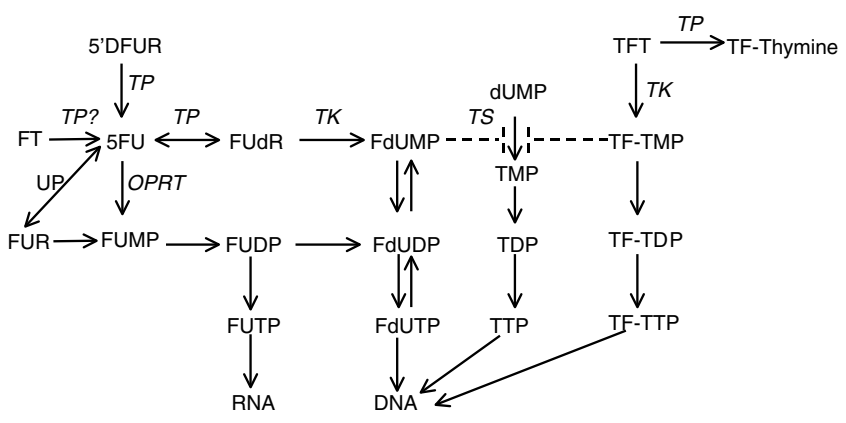

Figure I Scheme showing the possible metabolic pathways for 5FU via TP, UP (uridine phosphorylase) and orotate phosphoribosyltransferase (OPRT) and its different targets: TS inhibition via FdUMP and incorporation of FdUTP and FUTP into DNA and RNA, respectively. 5'-Deoxyfluorouridine is an intermediate in the conversion of Capecitabine to 5FU. Finally, the metabolic fate of TFT is shown, which can be degraded by TP or activated by TK, resulting in TS inhibition and DNA incorporation.

(Ansfield and Ramirez, 1971; Warrell Jr et al, 1979). It has shown efficacy in 5FU-resistant tumour cell lines bypassing the resistance mechanisms of these cells (Fukushima et al, 2000). Trifluorothymidine is inactivated by TP to trifluorothymine. This inactivation can be prevented by combining it with a specific thymidine phosphorylase inhibitor (TPI), which increased the bioavailability (Fukushima et al, 2000). This combination of TFT and TPI in the molar ratio 1:0.5, called TAS-102, is currently tested in phase I trials and can be administered orally (Thomas et al, 2002).

Also for another 5FU prodrug, Ftorafur (Ft), it has been postulated that it might be activated by TP (Kohne and Peters, 2000). Ftorafur is part of the oral formulation of UFT and S-1.

To determine to what extent TP plays a role in sensitivity to these fluoropyrimidines, we modulated TP activity in several colon cancer cell lines and one non small cell lung cancer (NSCLC) by inhibiting TP activity with TPI, and/or by overexpression of TP via stable transfection with a plasmid containing the cDNA for TP.

\section{MATERIALS AND METHODS}

\section{Chemicals}

Dulbecco's modified Eagle's medium (DMEM) RPMI 1640 and foetal calf serum (FCS) were obtained from Gibco BRL (Life Technology, Breda, The Netherlands). 5-Fluorouracil and 5'DFUR were purchased from Sigma Chemicals Co. (St Louis, MO, USA), Ft, TFT and TPI were provided by Taiho Pharmaceuticals (Hanno, Japan). Hybond ECL nitrocellulose membranes, Hyperfilm ECL and ECL (plus) detection kit were obtained from Amersham International (Buckinghamshire, UK). The primary polyclonal antibody was goat anti-human PD-ECGF (R\&D Systems, Abingdon, UK), the secondary antibody was peroxidase-conjugated rabbit anti-goat (Dako, Glostrup, Denmark). RNAzol was obtained from Campro Scientific (Veenendaal, The Netherlands), Moloney Murine Leukemia Virus Reverse Transcriptase (M-MLVRT) from Promega (Madison, WI, USA), deoxynucleotides (dNTPs), random hexamers and Taq polymerase from Pharmacia Biotech (Roosendaal, The Netherlands). All other chemicals were of analytical grade and commercially available.

\section{Cell lines and transfection}

The origins of the human colon carcinoma cell lines, Lovo, WiDR, HT29, SW1369, SW948, Colo320 and of that of the human NSCLC, H460 have been described previously (Tolis et al, 1999; van Triest et al, 1999). Colo320TP1 and H460TP2 are transfected variants of Colo320 and H460. All colon cell cancer lines were maintained in DMEM supplemented with $10 \%$ FCS, $\mathrm{H} 460$ was maintained in RPMI with $10 \%$ FCS. All cells were cultured at $37^{\circ} \mathrm{C}$ in a $5 \%$ fully humidified atmosphere. Cell lines were growing exponentially as monolayers during the course of all experiments.

Colo320 and H460 cells were transfected with TP. The pBABE puromycin vector containing human TP was a kind gift from Professor IJ Stratford (School of Pharmacy and Pharmaceutical Science, University of Manchester, UK) (Jones et al, 2002). Although the vector is designed for viral transfection, we used it for direct transfection without packaging the DNA. Cells were transfected with $10 \mu \mathrm{g}$ of vector using Superfect (Qiagen, Crawley, UK), according to the manufacturer's protocol. Selection was made using increasing concentrations of puromycin (ICN Biomedicals, Aurora, $\mathrm{OH}, \mathrm{USA}$ ). Independent clones were selected and tested for expression of TP by Western blotting. After selection, the clones were maintained in $1.5 \mu \mathrm{g} \mathrm{ml}^{-1}$ of puromycin and were passed once without puromycin before each experiment.

\section{Western blot analysis}

For determining TP expression, logarithmic growing cells were harvested and cell pellets were lysed by lysis buffer (1\% Triton X100; $150 \mathrm{~mm}$ Tris-HCL, pH 7.6; $5 \mathrm{~mm}$ EDTA), sonificated, and centrifuged, for $10 \mathrm{~min} 14000 \mathrm{~g}$ at $4^{\circ} \mathrm{C}$. Protein content of each sample was assayed using the Biorad assay (BioRad Laboratories, Richmond, CA, USA). Thirty micrograms protein of each sample was loaded, separated on a $12.5 \%$ SDS-PAGE gel and electroblotted onto a nitrocellulose membrane. Membranes were incubated overnight at room temperature in blocking buffer: $1 \%$ bovine serum albumin (BSA; Boehringer Mannheim, Germany),

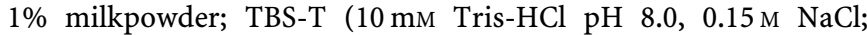
$0.05 \%$ Tween-20) to prevent aspecific antibody binding. After blocking, the membranes were incubated with the primary antibody goat anti-human PD-ECGF (1/1000), followed by horseradish peroxidase-conjugated rabbit anti-goat antibody (1/2000). Enhanced chemoluminescence (ECL plus) was used for detection, and protein expression was quantified by densitometric scanning (model GS-690 and Molecular analist, BioRad Laboratories, Richmond, CA, USA). Recombinant PD-ECGF (R\&D systems, Abingdon, UK) was used as a control in a dilution allowing optimal quantification in a linear range.

\section{Competitive template RT - PCR to determine TP mRNA expression levels}

The quantitative RT-PCR technique is based on the coamplification of a competitive template (CT) designed specifically for each different target. The principles have been described in detail elsewhere (Willey et al, 1998; Rots et al, 2000; Crawford et al, 2001).

RNA was extracted from $5 \times 10^{6}$ cells by the RNAzol ${ }^{\mathrm{TM}}$ method, checked for DNA contamination and reverse transcribed by random hexamers as described by the manufacturer with minimal modifications (Rots et al, 2000). Competitive templates were designed for $\beta$-actin (Rots et al, 2000) and TP, using the primer sets shown in Table 1. Competitive templates were produced from a cell line known to contain a considerable amount of TP activity (Colo320TP1). Competitive templates were dissolved in standardised solutions. Polymerase chain reaction was used for coamplification of the cDNA samples with $\mathrm{CTs}$ to ensure accurate quantification of the native target (NT). In order to normalise TP expression to that of $\beta$-actin, one single master mix was prepared for every cDNA sample containing PCR buffer $(1 \times)$, dNTPs $(200 \mu \mathrm{M})$, Taq polymerase $\left(0.02 \mathrm{U}_{\mu} \mathrm{l}^{-1}\right)$, sample cDNA $(1-$ $3 \mu \mathrm{l})$ and the appropriate CT mix $(1-3 \mu \mathrm{l})$ in a volume of $49 \mu \mathrm{l}$. One microlitre of premixed primers $\left(0.05 \mu \mathrm{g} \mu \mathrm{l}^{-1}\right)$ of TP and $\beta$-actin 
Table I Primers for RT-CT-PCR of TP to synthesise competitive templates ( $F$ and $C T$ ) and to coamplify CT and native template (NT) ( $F$ and R)

\begin{tabular}{llll}
\hline Target & Position & \multicolumn{1}{c}{$\mathbf{5}^{\prime} \rightarrow \mathbf{3}^{\prime}$ sequence } & Genbank \\
\hline PD-ECGF/TP & F 622 & ATC CAG AGC CCA GAG CAG ATG C & \multirow{2}{*}{ M63193 } \\
& R 1045 & TGG TGA CCA GGT CCC TTA AGT CTG & \\
& CT 893 & R+CCA ACC AGC GTC TTT GCC AG & \\
\hline
\end{tabular}

$\mathrm{F}$ is the forward primer, $\mathrm{R}$ is the reverse primer, $\mathrm{CT}$ is the primer used to generate the $\mathrm{CT}$.
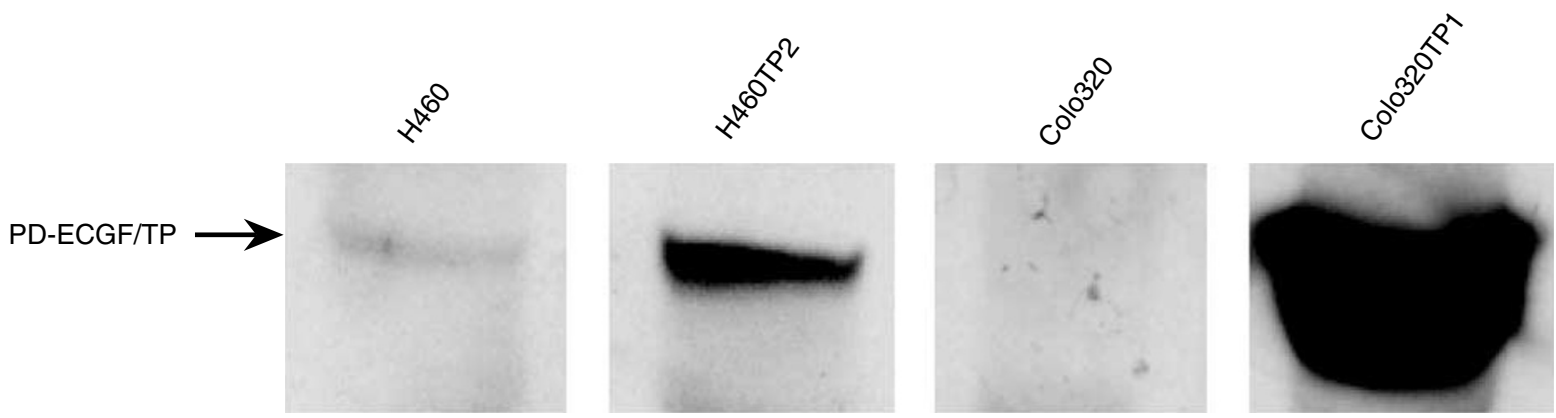

Figure 2 Western blot showing the TP expression of the H460 and Colo320 parental cells with their transfected counterparts H460TP2 and Colo320TPI, respectively.

primers were added to aliquots of the master mix and reaction mixtures were overlaid with $50 \mu \mathrm{l}$ of mineral oil. cDNA samples were amplified in a MJ Research PTC-2000 apparatus (Biozym, Landgraaf, the Netherlands) with 1 min steps of denaturation at $94^{\circ} \mathrm{C}$, primer annealing at $58^{\circ} \mathrm{C}$ and elongation at $72^{\circ} \mathrm{C}$ for 35 cycles starting with a hot start at $94^{\circ} \mathrm{C}$. PCR products were separated by $120 \mathrm{~V}$ electrophoresis for $2 \mathrm{~h}$ on $2 \%$ agarose gel containing $0.1 \mathrm{mg} \mathrm{ml}^{-1}$ ethidium bromide. The intensity of the NT and CT bands was quantified by digital image analysis using Scion Image (NIH, Bethesda, DC, USA). Concentrations of NT molecules of TP and $\beta$-actin in the cDNA samples were calculated by the ratio of NT/CT after amplification and the molarity of the CT mixture used as described previously (Rots et al, 2000). The relative expression of TP mRNA was given as the ratio of the concentration NT of TP $v s$ NT of $\beta$-actin.

\section{Thymidine phosphorylase activity}

The TP activity was determined using an assay previously described (Laurensse et al, 1988). Activity was measured using thymidine as a substrate by calculating its conversion to thymine. Depending on the TP activity, 30 or $60 \times 10^{6}$ cells ml ${ }^{-1} 50 \mathrm{~mm}$ Tris/ $1 \mathrm{~mm}$ EDTA ( $\mathrm{pH}$ 7.4) were used, which were sonificated and centrifuged at $21000 \mathrm{~g}$ at $4^{\circ} \mathrm{C}$. Fifty microlitres of $21000 \mathrm{~g}$ supernatant was mixed with $10 \mu \mathrm{l} 0.8 \mathrm{M} \mathrm{K} \mathrm{K}_{2} \mathrm{HPO}_{4}, 10 \mu \mathrm{l} 5 \mathrm{~mm}$ thymidine and $130 \mu \mathrm{l}$ TRIS/EDTA (pH 7.4) buffer, and incubated for 15,30 or $60 \mathrm{~min}$ at $37^{\circ} \mathrm{C}$. Thymidine phosphorylase inhibitor was used at a final concentration of $10 \mu \mathrm{M}$. The reaction was stopped by the addition of $50 \mu \mathrm{l} 40 \%$ trichloroacetic acid (TCA), neutralised and analysed by HPLC as described previously (Laurensse et al, 1988; van Triest et al, 2000).

\section{Growth inhibition experiments}

To study the role of TP in fluoropyrimidine sensitivity, the sulphorhodamine B (SRB, Sigma Chemicals, St Louis, MO, USA) staining method was used (Skehan et al, 1990; Keepers et al, 1991). It has been shown by us and others that this assay produces similar results as a clonogenic assay (Perez et al, 1993) and is an excellent method to measure growth inhibition of anticancer drugs. Briefly, cells were seeded at densities varying from 4000 to 15000 cells well $^{-1}$, depending on the doubling time, ensuring exponential growth during the experiment, with or without $10 \mu \mathrm{M}$ TPI. Drugs were added after $24 \mathrm{~h}$ at various concentrations and cells were incubated for $72 \mathrm{~h}$. Thereafter, cells were fixed with TCA, final concentration $10 \%$ and stained with SRB $(0.4 \% \mathrm{wt} / \mathrm{vol}$ In $1 \%$ acetic acid). Optical densities were measured on a Spectra Fluor (Tecan, Salzburg, Austria) at an absorbance of $540 \mathrm{~nm}$. Growth percentage was calculated as described previously, by setting absorbance of control cells after $72 \mathrm{~h}$ at $100 \%$ and absorbance at the time of drug addition at $0 \%$. Values were expressed as the concentration that corresponded to a cellular growth reduction of $50 \%\left(\mathrm{IC}_{50}\right)$ when compared to the value of the untreated control cells. The IC $_{50}$ 's are represented as means and standard error of at least three values. The term dose modifying factor (DMF) is used to express the effect of TPI and is calculated by $\left(\mathrm{IC}_{50}+\mathrm{TPI}\right) / \mathrm{IC}_{50}$.

\section{Statistics}

The one-tailed paired Student's $t$-test was used to study the effect of TPI on $\mathrm{IC}_{50}$ 's of the different fluoropyrimidines. For the correlations, the nonparametric Spearman's $\rho(r)$ was calculated. In some cases when specifically indicated, we also used the parametric Pearson's correlation test. Changes and correlations were considered significant when $P<0.05$.

\section{RESULTS}

\section{Transfection}

Colo320 and H460 cells were transfected with full-length human TP cDNA. After selection in puromycin, several clones of both cell lines were tested for TP expression by Western blotting (Figure 2). One high overexpressing clone of each cell line was selected for further experiments, Colo320 clone number 1 (Colo320TP1) and 


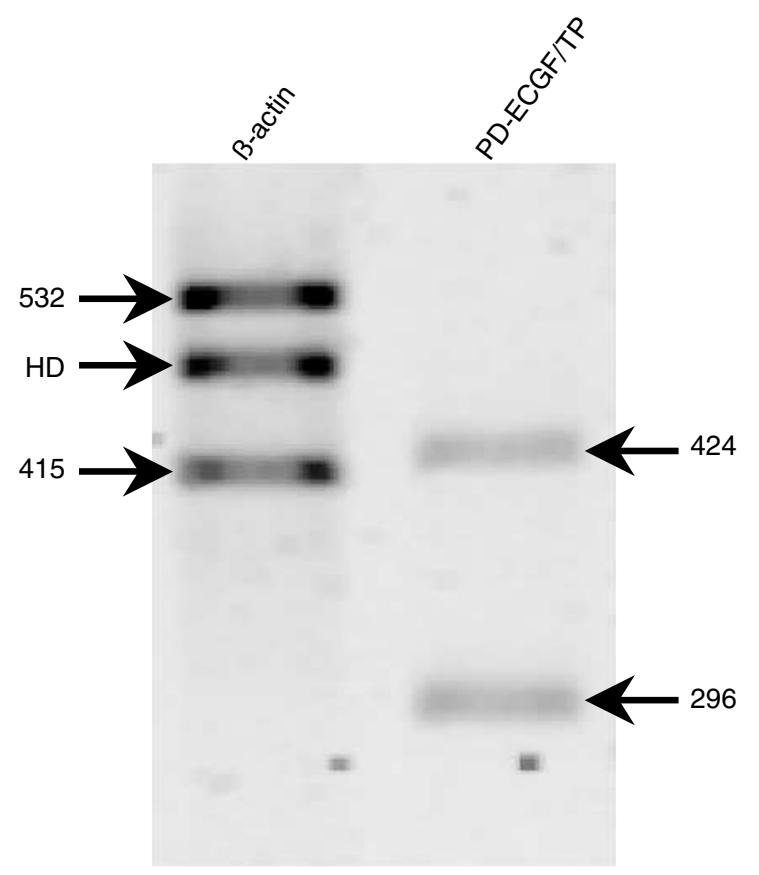

Figure 3 Representative example of an agarose gel on which PCR products are separated according to their expected sizes. The gels show three bands for $\beta$-actin: bands of 532 and $415 \mathrm{bp}$ are encoded by the forward and reverse primer for the native CDNA and CT, respectively, the third band is the heteroduplex consisting of native CDNA and CT. For TP, only two bands are visible, the native cDNA of 424 and 294 bp for the CT, the heteroduplex was formed occasionally. The bands were scanned and the OD was used to calculate a ratio between the native CDNA and CT. The contribution of the heteroduplex was calculated as described previously (Willey et al, 1998; Rots et al, 2000).

H460 clone number 2 (H460TP2). The clones had similar doubling times compared to the parental cell lines (data not shown).

\section{Thymidine phosphorylase protein, activity and mRNA expression}

In order to determine the correlation between TP activity and protein and mRNA expression, these parameters were determined with the described activity assay, Western blot and CT-RT-PCR, respectively. An example of an agarose gel with the PCR products and their expected size is shown in Figure 3. The mRNA expression results are depicted in Figure 4A. Thymidine phosphorylase activity varied considerably among the cell lines (Figure 4B), with a moderate activity in HT29, WiDR and Lovo cells. In all cell lines, the thymidine phosphorolysis could be completely inhibited by TPI except in SW 948, in which inhibition was only $34 \%$ while this activity could not be inhibited for SW 1398 by TPI. Unless otherwise stated, the measured phosphorolytic activity of the SW cell lines was adjusted according to the inhibition percentage by TPI, and this adjusted activity was used in the calculations. The H460 cell line had the highest activity of the nontransfected cells. Colo320 cells had no detectable activity but the stable transfected derivative Colo320TP1 had the highest activity $\left(70678 \mathrm{pmol} \mathrm{hr}^{-1} 10^{6}\right.$ cells $\left.^{-1}\right)$. Figure $4 \mathrm{C}$ shows a correlation plot between TP mRNA and TP activity for the nontransfected cell lines only. The mRNA expression was significantly correlated with TP activity. There was also a significant correlation between mRNA expression and TP protein expression, as determined by Western blot $(r=0.78, P<0.05)$, and protein expression also correlated significantly with TP activity $(r=0.75, P<0.05)$ in nontransfected cell lines. Comparable protein expression patterns
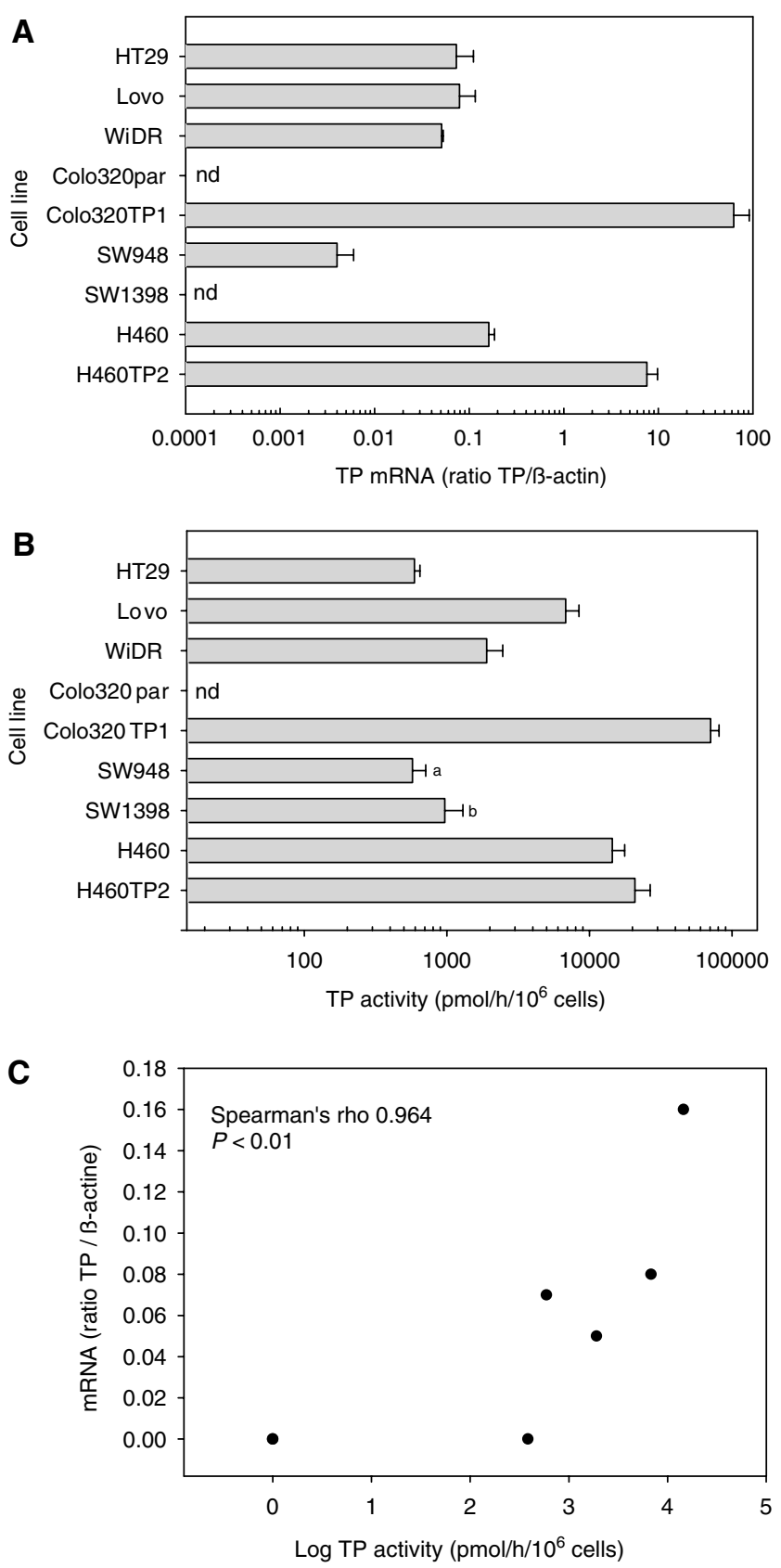

Figure 4 (A) Thymidine phosphorylase mRNA expression in the different cells lines. (B) Total TP activity of the different cell lines. Thymidine phosphorylase activity in SW948 cells could only be inhibited for 34\% by TPI (a), while TP activity of SWI 398 cells could not be inhibited by TPI (b) Thymidine phosphorylase inhibitor completely inhibited TP in the other cell lines. Protein content of the different cell lines varied from $79 \mu \mathrm{g}$ for Lovo to $194 \mu \mathrm{g}$ protein $10^{6}$ cells $^{-1}$ for SWI398. (C) Correlation plot of TP activity and mRNA expression of the nontransfected cell lines only. There was a strong positive correlation between the two parameters. The Pearson's linear correlation coefficient was $r=0.79 \quad(P<0.05)$ nd nondetectable.

(data not shown) were found using a commercially available ELISA (Roche, Almere, The Netherlands).

\section{Fluoropyrimidine sensitivity in relation to TP levels}

To determine the role of TP in the activation of 5FU, 5 DFUR, FT and the inactivation of TFT, we determined the effect of TPI on 
Table 2 IC 50 's of the fluoropyrimidines (expressed in $\mu \mathrm{M}$ ) in the presence or absence of TPI, for the different cell lines

\begin{tabular}{|c|c|c|c|c|c|c|c|c|c|c|c|c|}
\hline $\begin{array}{l}\text { HT29 } \\
\text { Lovo } \\
\text { WiDR } \\
\text { Colo320 } \\
\text { Colo320TPI } \\
\text { SW948 } \\
\text { SWI398 } \\
\text { H460 } \\
\text { H460TP2 }\end{array}$ & $\begin{array}{l}5.4 \pm 1.3 \\
1.1 \pm 0.1 \\
2.5 \pm 0.5 \\
2.3 \pm 0.2 \\
0.2 \pm 0.1 \\
3.1 \pm 1.0 \\
2.0 \pm 0.6 \\
2.0 \pm 0.2 \\
1.6 \pm 0.2\end{array}$ & $\begin{array}{r}6.6 \pm 0.2 \\
2.5 \pm 0.2 \\
4.7 \pm 1.0 \\
2.5 \pm 0.2 \\
2.8 \pm 0.3 \\
4.0 \pm 1.7 \\
3.2 \pm 0.6 \\
8.6 \pm 0.4 \\
11.1 \pm 1.0\end{array}$ & $\begin{array}{l}1.2^{2} \\
2.2^{\mathrm{b}} \\
1.9^{\mathrm{b}} \\
1.1^{\mathrm{b}} \\
14.7^{\mathrm{c}} \\
1.3^{-} \\
1.6^{\mathrm{c}} \\
4.3^{\mathrm{c}} \\
6.8^{\mathrm{c}}\end{array}$ & $\begin{array}{c}176.9 \pm 27.3 \\
24.9 \pm 5.1 \\
90.1 \pm 12.0 \\
61.7 \pm 5.8 \\
0.06 \pm 0.02 \\
208.9 \pm 7.6 \\
134.8 \pm 32.9 \\
10.9 \pm 1.7 \\
4.2 \pm 0.5\end{array}$ & $\begin{array}{c}275.8 \pm 15.9 \\
103.5 \pm 17.3 \\
222.5 \pm 25.0 \\
65.0 \pm 1.1 \\
81.0 \pm 10.5 \\
255.6 \pm 14.3 \\
202.0 \pm 37.4 \\
332.9 \pm 13.4 \\
275.0 \pm 16.1\end{array}$ & $\begin{array}{c}1.6 \\
4.2^{\mathrm{a}} \\
2.5^{\mathrm{b}} \\
1.1^{\mathrm{b}} \\
1396.6^{\mathrm{b}} \\
1.2^{2} \\
1.5^{\mathrm{c}} \\
30.5^{\mathrm{c}} \\
65.1^{\mathrm{c}}\end{array}$ & $\begin{array}{l}3.9 \pm 1.0 \\
0.5 \pm 0.1 \\
2.5 \pm 0.8 \\
0.4 \pm 0.1 \\
0.5 \pm 0.04 \\
N D \\
N D \\
0.6 \pm 0.1 \\
0.7 \pm 0.04\end{array}$ & $\begin{array}{l}3.7 \pm 0.7 \\
0.4 \pm .0 .1 \\
3.5 \pm 1.0 \\
0.4 \pm 0.1 \\
0.6 \pm 0.1 \\
N D \\
N D \\
0.6 \pm 0.03 \\
0.5 \pm 0.03\end{array}$ & $\begin{array}{l}0.9 \\
1.0 \\
1.4 \\
0.9 \\
1.1 \\
- \\
\overline{-} \\
0.9 \\
0.8\end{array}$ & $\begin{array}{c}201.1 \pm 37.9 \\
97.2 \pm 15.5 \\
203.9 \pm 44.9 \\
119.4 \pm 7.2 \\
N D \\
N D \\
275 \pm 39.7 \\
N D \\
N D\end{array}$ & $\begin{array}{c}283.2 \pm 81.3 \\
86 \pm 24.8 \\
236.1 \pm 27.8 \\
\mid 41.7 \pm 11.2 \\
N D \\
N D \\
191.4 \pm 22.1 \\
N D \\
N D\end{array}$ & $\begin{array}{l}1.4 \\
0.9 \\
1.2 \\
1.2 \\
- \\
0.7 \\
- \\
-\end{array}$ \\
\hline
\end{tabular}

Significant differences between drug and drug with TPI (Student $t$-test): ${ }^{a} P<0.05,{ }^{b} P<0.01,{ }^{c} P<0.00$ I

Thymidine phosphorylase inhibitor was present in a final concentration of $10 \mu \mathrm{M}, 24 \mathrm{~h}$ before drugs were added. DMF is the dose-modifying factor calculated as $\left(\mathrm{I} \mathrm{C}_{50}+\mathrm{TPI}\right) / \mathrm{I} \mathrm{C}_{50}$. $\mathrm{ND}=$ not done.

drug-induced growth inhibition (Table 2). The $\mathrm{IC}_{50} \mathrm{~s}$ for $5 \mathrm{FU}$ ranged from $0.2 \mu \mathrm{M}$ for Colo320TP1 to $5.4 \mu \mathrm{M}$ for HT29, and had an inverse correlation with TPI inhibitable activity $(r=-0.63$, $P<0.05)$. When overall phosphorolytic activity was used, $r=$ $-0.78(P<0.01)$. This high correlation, however, was mainly because of the contribution of the transfected cells; without these cells no significant correlation between TP activity and 5FU sensitivity was observed $(r=-0.28)$. The transfected Colo320TP1 cell line had an $\mathrm{IC}_{50}$ of $0.2 \mu \mathrm{M}$ for $5 \mathrm{FU}$ compared to $2.3 \mu \mathrm{M}$ for the parental cell line resulting in a relative sensitivity to $5 \mathrm{FU}$ of 11.5 . $\mathrm{IC}_{50}$ of $5 \mathrm{FU}$ was returned to parental level, $2.8 \mu \mathrm{M}$, when TP activity was inhibited by TPI resulting in a DMF of 14.7 for the transfected cell line.

A similar picture emerged for $5^{\prime} \mathrm{DFUR}$, with $\mathrm{IC}_{50}$ 's ranging from $0.058 \mu \mathrm{M}$ for Colo320TP1 to $208.9 \mu \mathrm{M}$ for SW1398. The sensitivity to 5 'DFUR inversely correlated with the TPI inhibitable TP activity $(r=-0.80, P<0.01)$. For the overall phosphorolytic activity, $r=-0.83 \quad(P<0.01)$. Wild-type Colo320 was, despite lacking measurable TP activity, sensitive to $5^{\prime} \mathrm{DFUR}$, with an $\mathrm{IC}_{50}$ of $61.7 \mu \mathrm{M}$, comparable to WiDR, $90.1 \mu \mathrm{M}$. This might indicate that there is another route of $5^{\prime}$ DFUR activation in Colo320 cells, such as another phosphorylase (Peters et al, 1989). There was no effect of TPI on the IC $_{50}$ 's for 5'DFUR in SW948 and SW1398 cell lines, corresponding with the low and lack of inhibition of phosphorolytic activity by TPI. The $\mathrm{IC}_{50}$ 's were higher for $5^{\prime}$ DFUR than for 5FU. A good correlation between 5FU and $5^{\prime}$ DFUR sensitivity would indicate that they would be activated by the same enzyme and would act on the same target(s). We observed a good correlation between all the $\mathrm{IC}_{50}$ 's of 5FU and $5^{\prime}$ DFUR $(r=0.85$, $P<0.01$ ), which is a reflection of a partly similar mechanism of activation.

Cell lines were sensitive to TFT with $\mathrm{IC}_{50}$ 's below $1 \mu \mathrm{M}$, except WiDR and HT29 which have an $\mathrm{IC}_{50}$ of 2.5 and $3.9 \mu \mathrm{M}$, respectively. Trifluorothymidine seems to be the most potent of the four tested fluoropyrimidines. In this setting of $72 \mathrm{~h}$ continuous exposure, the sensitivity to TFT was not related to TP activity, which was expected because TP can inactivate TFT.

The sensitivity for FT, the 5FU prodrug, ranged from 97.2 to $275 \mu \mathrm{M}$ for Lovo and SW 1398, respectively. There was no significant effect of TPI on the Ft sensitivity of the nontransfected colon cancer cells of the panel. There was no correlation between $\mathrm{IC}_{50}$ 's of $\mathrm{Ft}$ and $5 \mathrm{FU}$.

Thymidine phosphorylase inhibitor significantly increased $\mathrm{IC}_{50}$ 's for 5FU in WiDR, Lovo, H460, H460TP2 and Colo320TP1. The increase expressed as the DMF (ranging from 1.9 for WiDR to 14.7 for Colo320TP1), correlated with TP activity $(r=0.91$, $P<0.01$ ) (Figure 5). TPI also significantly increased the $\mathrm{IC}_{50}$ 's for 5 'DFUR in WiDR, Lovo, H460, H460TP2 and Colo320TP1 by adding TPI. The corresponding DMFs correlated with TP activity of the cells $(r=0.97, P<0.01)$, ranging from 2.5 for WiDR to 1396 for Colo320TP1.

Expression of TP mRNA also correlated with DMFs for 5FU and 5 DFUR ( $r=0.86$ and $0.95, P<0.01$, respectively), but not for the DMFs of TFT or Ft. Omission of the transfected cell lines resulted in $r=0.70(P<0.05)$ and $r=0.90(P<0.01)$ for 5FU and 5'DFUR, respectively. Thymidine phosphorylase protein levels correlated with DMF for $5^{\prime}$ DFUR $(r=0.70, P<0.05)$, but did not with DMFs for 5FU most likely because of the more accurate and sensitive nature of CT-RT - PCR compared with the Western blot.

\section{DISCUSSION}

In this study, we investigated the role of $\mathrm{TP}$ in the sensitivity to several fluoropyrimidines: the widely used chemotherapeutic agent 5FU, its prodrugs $5^{\prime} \mathrm{DFUR}$, FT and TFT, a novel oral fluoropyrimidine. The activation of $5^{\prime}$ DFUR was studied because it is the final intermediate in the activation of the oral fluoropyrimidine Capecitabine (Xeloda), which is postulated to be dependent upon TP.

There was a wide range of basal TP activity in our cell panel, varying from no activity for Colo320 cells to the intermediate activity of Lovo, WidR and HT29 cells to a high activity in H460 cells and the two transfectants H460TP2 and Colo320TP1. The SW1398 and SW948 cell lines also had an intermediate activity which converted TdR to thymine, but this could not be inhibited by TPI or could only by $34 \%$. This may be explained by the fact that not TP, but the closely related uridine phosphorylase (UP), catalysed this conversion. This is in contrast to the finding that transfection of MCF7 cells with the UP gene did not influence the effect of 5FU or $5^{\prime}$ DFUR (Cuq et al, 2001). Since Colo320 cells are sensitive for $5^{\prime}$ DFUR, despite the lack of detectable cleavage of $\mathrm{TdR}$, there is apparently a variability of substrate specificity of UP and TP from the different cell lines. el-Kouni et al (1993) described that specificity of TP for substrates varied between two different organs and cancers from mouse and humans. In Colo320 cells, another pyrimidine nucleoside phosphorylase may be active, that uses $5^{\prime}$ DFUR as a substrate but for which TdR is not a substrate (Woodman et al, 1980; Cao et al, 2002).

Using TPI and transfection, sensitivity of the cells to 5FU and 5'DFUR could be modulated either by inhibiting or enhancing TP activity to different extents. It seems that TP only plays a minor role in 5FU cytotoxicity in the nontransfected cell lines with DMFs varying from 2 to 4 , whereas in transfected cell lines the DMFs go up to 7 and 14 . In colon cancer cell lines with naturally occurring TP activity, the contribution as concluded by TPI inhibition is 

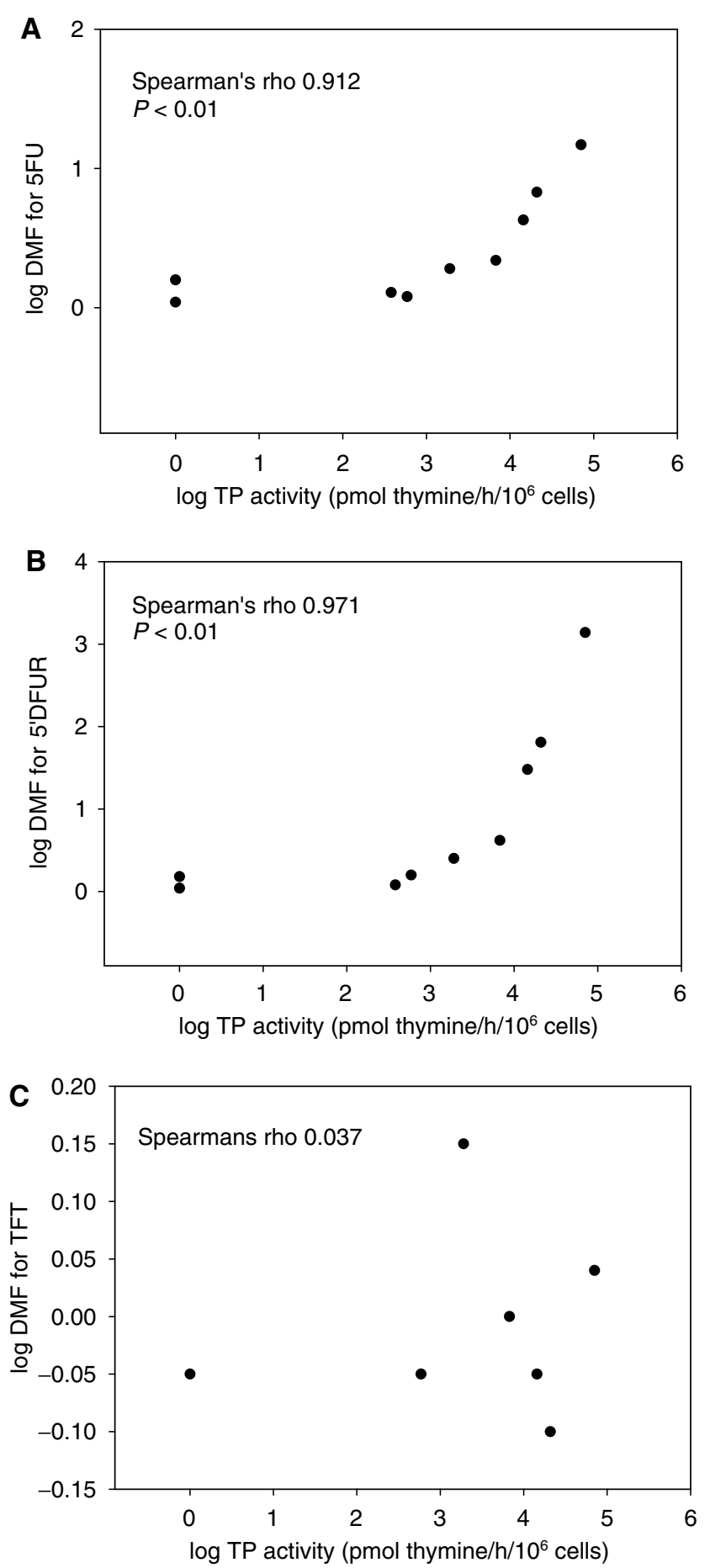

Figure 5 Correlation plots of TPI inhibitable TP activity of all cell lines with (A) DMF of 5FU, (B) DMF 5'DFUR and (C) DMF TFT.

relatively low. Uptake and other activation pathways such as UP and OPRT (Peters et al, 1989) seem much more important. Thymidine phosphorylase may play a more important role when an additional source for the substrate for the activation reaction dR-1-P is provided. For $5^{\prime}$ DFUR, it can be concluded that the role of $\mathrm{TP}$, in determining the $\mathrm{IC}_{50}$, is larger with DMFs varying from 2.5 to 30 for nontransfected cell lines, and varying up to 65 and 1400 in the transfected cell lines. In previous studies (Patterson et al, 1995; Kato et al, 1997; Evrard et al, 1999a, b; Marchetti et al, 2001), the effect of TP on 5FU and 5'DFUR was also demonstrated, although the enhanced sensitivity of Colo320TP1 for 5'DFUR (1396-fold) was extremely high. For example, MCF7-transfected cells had an increased sensitivity, of 165-fold (Patterson et al, 1995), PC9-transfected cells, 153-fold (Kato et al, 1997), and PRObtransfected cells, 10-fold (Marchetti et al, 2001). In these studies, there was also increased sensitivity to 5FU but always lower than for $5^{\prime}$ DFUR. Other studies report that after transfection the sensitivity increase for $5 \mathrm{FU}$ was higher than that of $5^{\prime} \mathrm{DFUR}$ (Evrard et al, 1999a, b), which is possibly because of an increased availability of dR-1-P in these cells, necessary for activation of 5FU by TP. Increase in dR-1-P availability in cells greatly enhances $5 \mathrm{FU}$ sensitivity mediated by TP (Peters et al, 1987; Ciccolini et al, 2001). This different role of $\mathrm{TP}$ in $5 \mathrm{FU}$ and $5^{\prime} \mathrm{DFUR}$ cytotoxicity is because of the fact that $5^{\prime}$ DFUR is a prodrug of $5 \mathrm{FU}$ and needs an extra activation step. Activation of $5^{\prime}$ DFUR can only occur through its conversion to $5 \mathrm{FU}$, but that of $5 \mathrm{FU}$ can be mediated by three different pathways. Thereafter, the drugs might exert a similar mechanism of action.

There was no effect on Ft in the tested nontransfected cell lines. Recent studies show that the activation of $\mathrm{Ft}$ is mediated by cytochrome P450 enzymes (Komatsu et al, 2000), which have a considerable but variable expression in colon cancer cell lines $(\mathrm{Yu}$ et al, 2001) which explains the lack of correlation in $\mathrm{IC}_{50}$ 's between $\mathrm{Ft}$ and 5FU.

There was no effect of TPI on TFT sensitivity, which was unexpected because it has been demonstrated that TFT is a good substrate for TP (Fukushima et al, 2000). We expected to see a decrease of $\mathrm{IC}_{50}$ for TFT in the cell lines with high TP expression when given in combination with TPI. However, since the $72 \mathrm{~h}$ continuous exposure might be too long to detect an effect of TPI, we decreased drug exposure times to $2 \mathrm{~h}$ followed by a $72 \mathrm{~h}$ drugfree growth, but also in this setting TPI did not affect TFT sensitivity (data not shown). Possibly activation of TFT by thymidine kinase (TK) is very efficient, preventing inactivation by TP. Trifluorothymidine possibly acts by TS inhibition and DNA incorporation. However, orally administered TFT in combination with TPI (TAS-102) seems to prevent systemic degradation (e.g. liver) of TFT resulting in increased plasma levels compared to TFT alone (Fukushima et al, 2000).

Use of TPI might also have an indirect effect on the sensitivity of the different fluoropyrimidines; TPI can prevent TdR degradation which might rescue cytotoxicity of 5FU and $5^{\prime}$ DFUR. Patterson et al (1995, 1998) indeed described that high TP can moderate thymidine dependent rescue of TS inhibited cells. This of course depends on the intracellular TdR concentration.

We found a good correlation between mRNA expression and activity, mRNA expression and protein expression, indicating that mRNA screening of tumour samples might be sufficient to characterise the TP status, requiring a low amount of material to determine TP status. However, cell lines are homogeneous, while tumours are heterogeneous with unknown amounts of tumour, stroma and infiltrating cells, which can all contain considerable amounts of TP expression (Takahashi et al, 1996; Giatromanolaki et al, 1998; Matsumura et al, 1998; van Triest et al, 2000).

In conclusion, we determined that there is a small role of TP in the cytotoxicity of 5FU, and that this role could be increased when TP expression was increased. For $5^{\prime}$ DFUR activation, the role of TP is much more pronounced. FT sensitivity was not dependent upon TP in the tested cell lines.

\section{ACKNOWLEDGEMENT}

This study was sponsored by the Spinoza award from NWO, received by Professor Dr HM Pinedo. 


\section{REFERENCES}

Ackland SP, Peters GJ (1999) Thymidine phosphorylase: its role in sensitivity and resistance to anticancer drugs. Drug Resist Updat 2: $205-214$

Ansfield FJ, Ramirez G (1971) Phase I and II studies of 2'-deoxy-5(trifluoromethyl)-uridine (NSC- 75520). Cancer Chemother Rep 55: 205208

Cao D, Russell RL, Zhang D, Leffert JJ, Pizzorno G (2002) Uridine phosphorylase $(-/-)$ murine embryonic stem cells clarify the key role of this enzyme in the regulation of the pyrimidine salvage pathway and in the activation of fluoropyrimidines. Cancer Res 62: 2313-2317

Ciccolini J, Cuq P, Evrard A, Giacometti S, Pelegrin A, Aubert C, Cano JP, Milano G, Iliadis A (2001) Combination of thymidine phosphorylase gene transfer and deoxinosine treatment greatly enhances 5-fluorouracil antitumor activity in vitro and in vivo. Mol Cancer Ther 1: 133-139

Crawford EL, Peters GJ, Noordhuis P, Rots MG, Vondracek M, Grafstrom RC, Lieuallen K, Lennon G, Zahorchak RJ, Georgeson MJ, Wali A, Lechner JF, Fan PS, Kahaleh MB, Khuder SA, Warner KA, Weaver DA, Willey JC (2001) Reproducible gene expression measurement among multiple laboratories obtained in a blinded study using standardized RT (StaRT)-PCR. Mol Diagn 6: 217-225

Cuq P, Rouquet C, Evrard A, Ciccolini J, Vian L, Cano JP (2001) Fluoropyrimidine sensitivity of human MCF-7 breast cancer cells stably transfected with human uridine phosphorylase. Br J Cancer 84: 16771680

el Kouni MH, el Kouni MM, Naguib FN (1993) Differences in activities and substrate specificity of human and murine pyrimidine nucleoside phosphorylases: implications for chemotherapy with 5-fluoropyrimidines [published erratum in Cancer Res 1993; 53: 4738]. Cancer Res 53: $3687-3693$

Evrard A, Cuq P, Ciccolini J, Vian L, Cano JP (1999a) Increased cytotoxicity and bystander effect of 5-fluorouracil and 5'-deoxy-5-fluorouridine in human colorectal cancer cells transfected with thymidine phosphorylase. Br J Cancer 80: $1726-1733$

Evrard A, Cuq P, Robert B, Vian L, Pelegrin A, Cano JP (1999b) Enhancement of 5-fluorouracil cytotoxicity by human thymidinephosphorylase expression in cancer cells: in vitro and in vivo study. Int J Cancer 80: $465-470$

Fox SB, Engels K, Comley M, Whitehouse RM, Turley H, Gatter KC, Harris AL (1997) Relationship of elevated tumour thymidine phosphorylase in node-positive breast carcinomas to the effects of adjuvant CMF. Ann Oncol 8: $271-275$

Fox SB, Moghaddam A, Westwood M, Turley H, Bicknell R, Gatter KC, Harris AL (1995) Platelet-derived endothelial cell growth factor/ thymidine phosphorylase expression in normal tissues: an immunohistochemical study. J Pathol 176: $183-190$

Fukushima M, Suzuki N, Emura T, Yano S, Kazuno H, Tada Y, Yamada Y, Asao T (2000) Structure and activity of specific inhibitors of thymidine phosphorylase to potentiate the function of antitumor $2^{\prime}$-deoxyribonucleosides. Biochem Pharmacol 59: 1227-1236

Furukawa T, Yoshimura A, Sumizawa T, Haraguchi M, Akiyama S, Fukui K, Ishizawa M, Yamada Y (1992) Angiogenic factor [letter]. Nature 356: 668 Giatromanolaki A, Koukourakis MI, Kakolyris S, Kaklamanis L, Barbatis K, O'Byrne KJ, Theodosssiou D, Harris AL, Gatter KC (1998) Focal expression of thymidine phosphorylase associates with CD31 positive lymphocytic aggregation and local neo-angiogenesis in non-small cell lung cancer. Anticancer Res 18: $71-76$

Ikeguchi M, Oka S, Saito H, Kondo A, Tsujitani S, Maeta M, Kaibara N (1999) Clinical significance of the detection of thymidine phosphorylase activity in esophageal squamous cell carcinomas. Eur Surg Res 31: $357-$ 363

Ishikawa F, Miyazono K, Hellman U, Drexler H, Wernstedt C, Hagiwara K, Usuki K, Takaku F, Risau W, Heldin CH (1989) Identification of angiogenic activity and the cloning and expression of platelet-derived endothelial cell growth factor. Nature 338: 557-562

Jones A, Fujiyama C, Turner K, Cranston D, Williams K, Stratford I, Bicknell R, Harris AL (2002) Role of thymidine phosphorylase in an in vitro model of human bladder cancer invasion. J Urol 167: 1482-1486

Kato Y, Matsukawa S, Muraoka R, Tanigawa N (1997) Enhancement of drug sensitivity and a bystander effect in PC-9 cells transfected with a plateletderived endothelial cell growth factor thymidine phosphorylase cDNA. Br J Cancer 75: 506-511

Keepers YP, Pizao PE, Peters GJ, Ark-Otte J, Winograd B, Pinedo HM (1991) Comparison of the sulforhodamine B protein and tetrazolium
(MTT) assays for in vitro chemosensitivity testing. Eur J Cancer 27: 897 900

Kohne CH, Peters GJ (2000) UFT: mechanism of drug action. Oncology (Huntingt) 14: $13-18$

Koide N, Watanabe H, Yazawa K, Adachi W, Amano J (1999) Immunohistochemical expression of thymidine phosphorylase/plateletderived endothelial cell growth factor in squamous cell carcinoma of the esophagus. Hepatogastroenterology 46: 944-951

Komatsu T, Yamazaki H, Shimada N, Nakajima M, Yokoi T (2000) Roles of cytochromes $P 4501 \mathrm{~A} 2,2 \mathrm{~A} 6$, and $2 \mathrm{C} 8$ in 5-fluorouracil formation from tegafur, an anticancer prodrug, in human liver microsomes. Drug Metab Dispos 28: $1457-1463$

Laurensse EJ, Pinedo HM, Peters GJ (1988) A sensitive non-radioactive assay for pyrimidine nucleoside phosphorylase using reversed-phase high performance liquid chromatography. Clin Chim Acta 178: $71-78$

Marchetti S, Chazal M, Dubreuil A, Fischel JL, Etienne MC, Milano G (2001) Impact of thymidine phosphorylase surexpression on fluoropyrimidine activity and on tumour angiogenesis. Br J Cancer 85: 439-445

Matsumura M, Chiba Y, Lu C, Amaya H, Shimomatsuya T, Horiuchi T, Muraoka R, Tanigawa N (1998) Platelet-derived endothelial cell growth factor/thymidine phosphorylase expression correlated with tumor angiogenesis and macrophage infiltration in colorectal cancer. Cancer Lett 128: $55-63$

Miwa M, Ura M, Nishida M, Sawada N, Ishikawa T, Mori K, Shimma N, Umeda I, Ishitsuka H (1998) Design of a novel oral fluoropyrimidine carbamate, capecitabine, which generates 5 -fluorouracil selectively in tumours by enzymes concentrated in human liver and cancer tissue. Eur J Cancer 34: 1274-1281

Miyazono K, Okabe T, Urabe A, Takaku F, Heldin CH (1987) Purification and properties of an endothelial cell growth factor from human platelets. J Biol Chem 262: $4098-4103$

Moghaddam A, Bicknell R (1992) Expression of platelet-derived endothelial cell growth factor in Escherichia coli and confirmation of its thymidine phosphorylase activity. Biochemistry 31: $12141-12146$

Moghaddam A, Zhang HT, Fan TP, Hu DE, Lees VC, Turley H, Fox SB, Gatter KC, Harris AL, Bicknell R (1995) Thymidine phosphorylase is angiogenic and promotes tumor growth. Proc Natl Acad Sci USA 92: $998-1002$

O’Brien T, Cranston D, Fuggle S, Bicknell R, Harris AL (1995) Different angiogenic pathways characterize superficial and invasive bladder cancer. Cancer Res 55: 510-513

O'Brien TS, Fox SB, Dickinson AJ, Turley H, Westwood M, Moghaddam A, Gatter KC, Bicknell R, Harris AL (1996) Expression of the angiogenic factor thymidine phosphorylase/platelet-derived endothelial cell growth factor in primary bladder cancers. Cancer Res 56: 4799-4804

Patterson AV, Talbot DC, Stratford IJ, Harris AL (1998) Thymidine phosphorylase moderates thymidine-dependent rescue after exposure to the thymidylate synthase inhibitor ZD1694 (Tomudex) in vitro. Cancer Res 58: $2737-2740$

Patterson AV, Zhang H, Moghaddam A, Bicknell R, Talbot DC, Stratford IJ, Harris AL (1995) Increased sensitivity to the prodrug $5^{\prime}$-deoxy-5fluorouridine and modulation of 5-fluoro- $2^{\prime}$-deoxyuridine sensitivity in MCF-7 cells transfected with thymidine phosphorylase. Br J Cancer 72: $669-675$

Perez RP, Godwin AK, Handel LM, Hamilton TC (1993) A comparison of clonogenic, microtetrazolium and sulforhodamine B assays for determination of cisplatin cytotoxicity in human ovarian carcinoma cell lines. Eur J Cancer 29A: 395-399

Peters GJ, Braakhuis BJ, de Bruijn EA, Laurensse EJ, van Walsum M, Pinedo HM (1989) Enhanced therapeutic efficacy of $5^{\prime}$ deoxy-5-fluorouridine in 5-fluorouracil resistant head and neck tumours in relation to 5fluorouracil metabolising enzymes. Br J Cancer 59: 327 - 334

Peters GJ, Laurensse E, Leyva A, Pinedo HM (1987) Purine nucleosides as cell-specific modulators of 5-fluorouracil metabolism and cytotoxicity. Eur J Cancer Clin Oncol 23: 1869-1881

Rots MG, Willey JC, Jansen G, Van Zantwijk CH, Noordhuis P, DeMuth JP, Kuiper E, Veerman AJ, Pieters R, Peters GJ (2000) mRNA expression levels of methotrexate resistance-related proteins in childhood leukemia as determined by a standardized competitive template-based RT - PCR method. Leukemia 14: 2166-2175

Saito H, Tsujitani S, Oka S, Kondo A, Ikeguchi M, Maeta M, Kaibara N (1999) The expression of thymidine phosphorylase correlates with 
Thymidine phosphorylase and fluoropyrimidine sensitivity $M$ de Bruin et al

angiogenesis and the efficacy of chemotherapy using fluorouracil derivatives in advanced gastric carcinoma. Br J Cancer 81: 484-489

Skehan P, Storeng R, Scudiero D, Monks A, McMahon J, Vistica D, Warren JT, Bokesch H, Kenney S, Boyd MR (1990) New colorimetric cytotoxicity assay for anticancer-drug screening. J Natl Cancer Inst 82: 1107-1112

Takahashi Y, Bucana CD, Liu W, Yoneda J, Kitadai Y, Cleary KR, Ellis LM (1996) Platelet-derived endothelial cell growth factor in human colon cancer angiogenesis: role of infiltrating cells. J Natl Cancer Inst 88: 11461151

Takebayashi Y, Akiyama S, Akiba S, Yamada K, Miyadera K, Sumizawa T, Yamada Y, Murata F, Aikou T (1996b) Clinicopathologic and prognostic significance of an angiogenic factor, thymidine phosphorylase, in human colorectal carcinoma [see comments]. J Natl Cancer Inst 88: 1110-1117

Takebayashi Y, Miyadera K, Akiyama S, Hokita S, Yamada K, Akiba S, Yamada Y, Sumizawa T, Aikou T (1996a) Expression of thymidine phosphorylase in human gastric carcinoma. Jpn J Cancer Res 87: 288295

Thomas MB, Hoff PM, Carter S, Bland G, Lassere Y, Wolff R, Xiong H, Hayakawa T, Abbruzzese J (2002) A dose-finding, safety and pharmacokinetics study of TAS-102, an antitumor/antiangiogenic agent given orally on a once-daily schedule for five days every three weeks in patients with solid tumors. Proc Am Assoc Cancer Res 43: 554 (\#2754)

Tolis C, Peters GJ, Ferreira CG, Pinedo HM, Giaccone G (1999) Cell cycle disturbances and apoptosis induced by topotecan and gemcitabine on human lung cancer cell lines. Eur J Cancer 35: 796-807

Usuki K, Saras J, Waltenberger J, Miyazono K, Pierce G, Thomason A, Heldin CH (1992) Platelet-derived endothelial cell growth factor has thymidine phosphorylase activity. Biochem Biophys Res Commun 184: $1311-1316$

van Triest B, Pinedo HM, Blaauwgeers JL, van Diest PJ, Schoenmakers PS, Voorn DA, Smid K, Hoekman K, Hoitsma HF, Peters GJ (2000) Prognostic role of thymidylate synthase, thymidine phosphorylase/ platelet-derived endothelial cell growth factor, and proliferation markers in colorectal cancer. Clin Cancer Res 6: $1063-1072$

van Triest B, Pinedo HM, van Hensbergen Y, Smid K, Telleman F, Schoenmakers PS, van der Wilt CL, van Laar JA, Noordhuis P, Jansen G, Peters GJ (1999) Thymidylate synthase level as the main predictive parameter for sensitivity to 5-fluorouracil, but not for folate-based thymidylate synthase inhibitors, in 13 nonselected colon cancer cell lines. Clin Cancer Res 5: 643-654

Warrell Jr RP, Currie V, Kempin S, Young C (1979) Phase II trial of pyrazofurin, alone and in combination with trifluorothymidine, in nonHodgkin's lymphoma. Cancer Treat Rep 63: 1423-1425

Willey JC, Crawford EL, Jackson CM, Weaver DA, Hoban JC, Khuder SA, DeMuth JP (1998) Expression measurement of many genes simultaneously by quantitative RT-PCR using standardized mixtures of competitive templates. Am J Respir Cell Mol Biol 19: 6-17

Woodman PW, Sarrif AM, Heidelberger C (1980) Specificity of pyrimidine nucleoside phosphorylases and the phosphorolysis of 5-fluoro- $2^{\prime}$ deoxyuridine. Cancer Res 40: 507 - 511

Yu LJ, Matias J, Scudiero DA, Hite KM, Monks A, Sausville EA, Waxman DJ (2001) P450 enzyme expression patterns in the NCI human tumor cell line panel. Drug Metab Dispos 29: 304-312 